OPEN ACCESS

Edited by:

Zhang Chengjun,

Lanzhou University, China

Reviewed by:

Xianyong Cao,

Institute of Tibetan Plateau Research

(CAS), China

Zhixin $\mathrm{HAO}$,

Chinese Academy of Sciences, China

*Correspondence:

Xingqi Liu

xqliu@cnu.edu.cn

Specialty section:

This article was submitted to

Quaternary Science, Geomorphology

and Paleoenvironment,

a section of the journal

Frontiers in Earth Science

Received: 27 November 2021

Accepted: 28 December 2021

Published: 24 January 2022

Citation:

Zhang Q, Liu X and Feng S (2022) Factors Influencing the Seasonal Flux of the Varved Sediments of Kusai Lake on the Northern Tibetan Plateau During

the Last $\sim 2280$ years.

Front. Earth Sci. 9:823258

doi: 10.3389/feart.2021.823258

\section{Factors Influencing the Seasonal Flux of the Varved Sediments of Kusai Lake on the Northern Tibetan Plateau During the Last $\sim 2280$ years}

\author{
Qi Zhang, Xingqi Liu* and Shengnan Feng \\ College of Resource Environment and Tourism, Capital Normal University, Beijing, China
}

The varved sediments of Kusai Lake on the northern Tibetan Plateau are rhythmically laminated with the interaction of dark and light layers formed during winter and summer within a year. This provides opportunities to explore the seasonal fluxes of varves and, thus, assess the potential for annual-resolution climate reconstruction. Here, we define a season index (SI) based on the difference in thickness between the light and dark layers, to evaluate the factors influencing the seasonal flux of varved Kusai Lake sediments. A positive SI represents more summer flux, and a negative SI indicates more winter flux. The results showed that the summer flux was higher than the winter flux in most of the last 2280 years. The summer flux had periodicities of approximately 2.3-2.9, 27, and 99 years at the 99\% confidence level and approximately 15-16, 36 and 285 years at the 95\% confidence level, indicating that summer flux is affected mainly by solar activity (Gleissberg and 350 unnamed cycle) at centennial scales, by the Pacific Decadal Oscillation (Pacific Decadal Oscillation with a period of 15-25 years) at decadal scales, and by the Quasibiennial Oscillation (Quasi-biennial Oscillation with a period of 2-3 years) at interannual scales. Noticeable increasing spikes of high winter flux corresponded well to lower solar activity and stronger Siberian high pressure (SH). The periods of high and low winter flux are generally related to the negative and positive phases of the North Atlantic Oscillation and Atlantic Multidecadal Oscillation respectively, during the last 1000 years.

Keywords: Tibetan Plateau, varve, season index, summer flux, winter flux

\section{INTRODUCTION}

The Tibetan Plateau (TP) is widely referred to as 'the roof of the world'. As there are numerous glaciers and the origins of major Asian rivers on the TP, it was recently acknowledged as the Asian Water Tower (Yao et al., 2015; Yao et al., 2019). In recent 50 years, the temperature rising rate is more than twice that of the global average (Chen et al., 2015), implying that the TP is sensitive to climate warming. In addition, one-third of the TP expands into the troposphere, releasing sensible and latent heat fluxes that drive intense monsoon circulations and strongly influence global circulation patterns (Thompson et al., 1997). Therefore, the TP has become a hotspot in climate change research because of its sensitivity to global warming and its strong effect on global environmental changes (Liu and Chen, 2000; Hou et al., 2012; Yao et al., 2012; Hou et al., 2016; Wu et al., 2018; Li et al., 2020). Present atmospheric circulation patterns show that the climate on the TP is influenced by the Asian summer monsoon in summer and is mainly controlled by the Asian winter monsoon and the westerlies in 


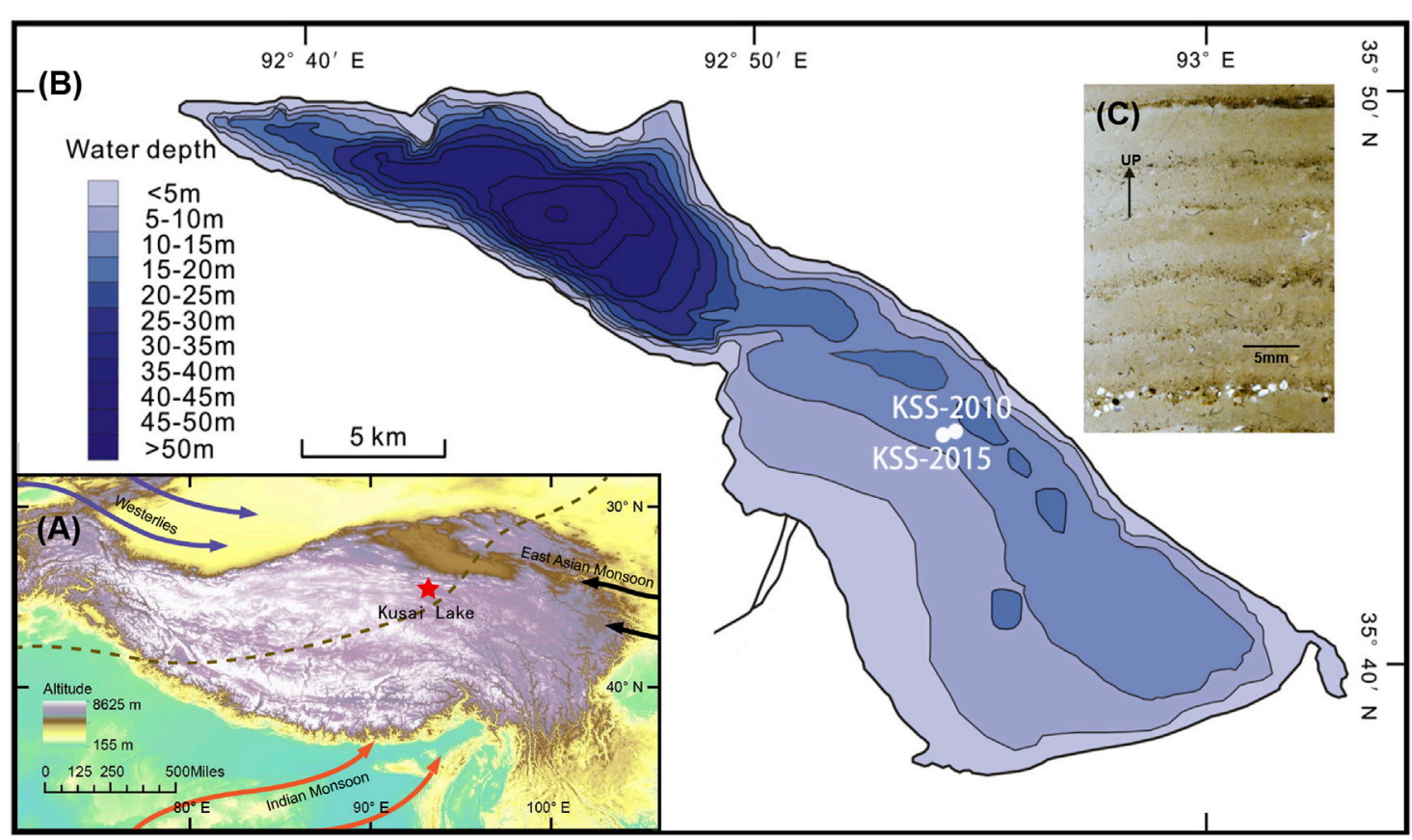

FIGURE 1 | Location of Kusai Lake on the TP, which is influenced by the Indian monsoon, westerlies, and East Asian monsoon (A), the boundary of modern summer monsoon (thick dashed line) is modified from Chen et al. (2010). The coring site of Lake Kusai (B). Water depth was measured in 2002. Macroscopic photograph of varves from Kusai Lake (C) (Chen, 2017).

winter (Yao et al., 2013). The TP climate changes are also modulated by the Asian monsoon and the westerly jet at different time scales (Figure 1A) (Chen et al., 2008; An et al., 2012; Chiang et al., 2015; Zhu et al., 2015; Hou et al., 2017). In recent decades, many paleoclimate records on the TP have been reconstructed based on tree rings (Kang et al., 2000; Liu et al., 2009; Zhang et al., 2014; Chen F. et al., 2016), ice cores (Yao et al., 1996; Thompson et al., 2003; Bao, 2004; Thompson et al., 2006), and varved lake sediments (Chu et al., 2011; Liu et al., 2014b; Ji et al., 2021) at the interannual and interdecadal scales, and lake sediments at centennial to glacial-interglacial scales (Liu et al., 2006; He et al., 2013b; Liu et al., 2014a; Aichner et al., 2015; Li et al., 2015; Li X. et al., 2019). However, these paleoclimate reconstructions are unable to discriminate seasonal climate signals and their influencing factors, as the resolution of many archives is insufficient. Varved lake sediments generally comprise alternating layers deposited during summer and winter for 1 year, which allows us to discuss climate changes as seasonal-scale processes. Based on varved sediments from Kusai Lake located in the northern TP, the temperature and dust variations over the past $\sim 1600$ years were reconstructed (Liu et al., 2014b). However, what factors influence the seasonal flux of the varved sediments of Kusai Lake remains unknown. Here, we extended the records of summer and winter flux back to 2280 years ago based on the thicknesses of light (LT) and dark (DT) layers of varved sediments from Kusai Lake. Then, spectral and wavelet analysis and regional comparisons were used to identify regular periodicities and to evaluate possible connections of summer and winter fluxes to known modes of natural variability at different timescales.

\section{MATERIALS AND METHODS}

\section{Regional Setting}

Kusai Lake is located at $35^{\circ} 33^{\prime}-35^{\circ} 50^{\prime} \mathrm{N}, 92^{\circ} 37^{\prime}-93^{\circ} 03^{\prime} \mathrm{E}$ in the northeastern Hoh Xil region of the TP (Figure 1), $4475 \mathrm{~m}$ above sea level [a. s. 1]. It is an elongated lake with a surface area of $254.4 \mathrm{~km}^{2}$ and a drainage basin of $3700 \mathrm{~km}^{2}$ (Hu, 1994; Li et al., 1996; Wang and Dou, 1998). The water depth is between 10 and $50 \mathrm{~m}$ and is deeper in the northwest and shallower in the southeastern part of the lake (Li et al., 1996; Wang and Dou, 1998). The lake is fed mainly by the Kusai River, which originates to the west of the lake on the Daxue Mountain (5863 m a. s. 1), with a recharge coefficient of 13.1 (Wang and Dou, 1998; Chen, 2017).

The climate of the northern TP is characterized by a semiarid climate. Modern meteorological records indicate a mean annual temperature of the lake area of approximately $-5.4^{\circ} \mathrm{C}$, a mean annual precipitation of approximately $275 \mathrm{~mm}$, and a potential annual evaporation of approximately $1300 \mathrm{~mm}$ ( $\mathrm{Li}$ et al., 1996; Wang and Dou, 1998). Regional precipitation is mainly concentrated in summer (Cui et al., 2021). However, the climate in winter is always cold and dry with a high frequency of dust storms (Zhao and Zhou, 2002; Chen, 2017). The modern vegetation around Kusai Lake is alpine steppe dominated by drought-resistant Artemisia and Poaceae, and alpine meadow dominated by hygrophilous Cyperaceae (Wang et al., 2012; Cui et al., 2021).

\section{Core Sampling and Methods Overview}

Two sediment cores with lengths of $3.64 \mathrm{~m}$ (KSS-2010) and $5.2 \mathrm{~m}$ (KSS-2015) were obtained from the southeastern part of Kusai Lake 


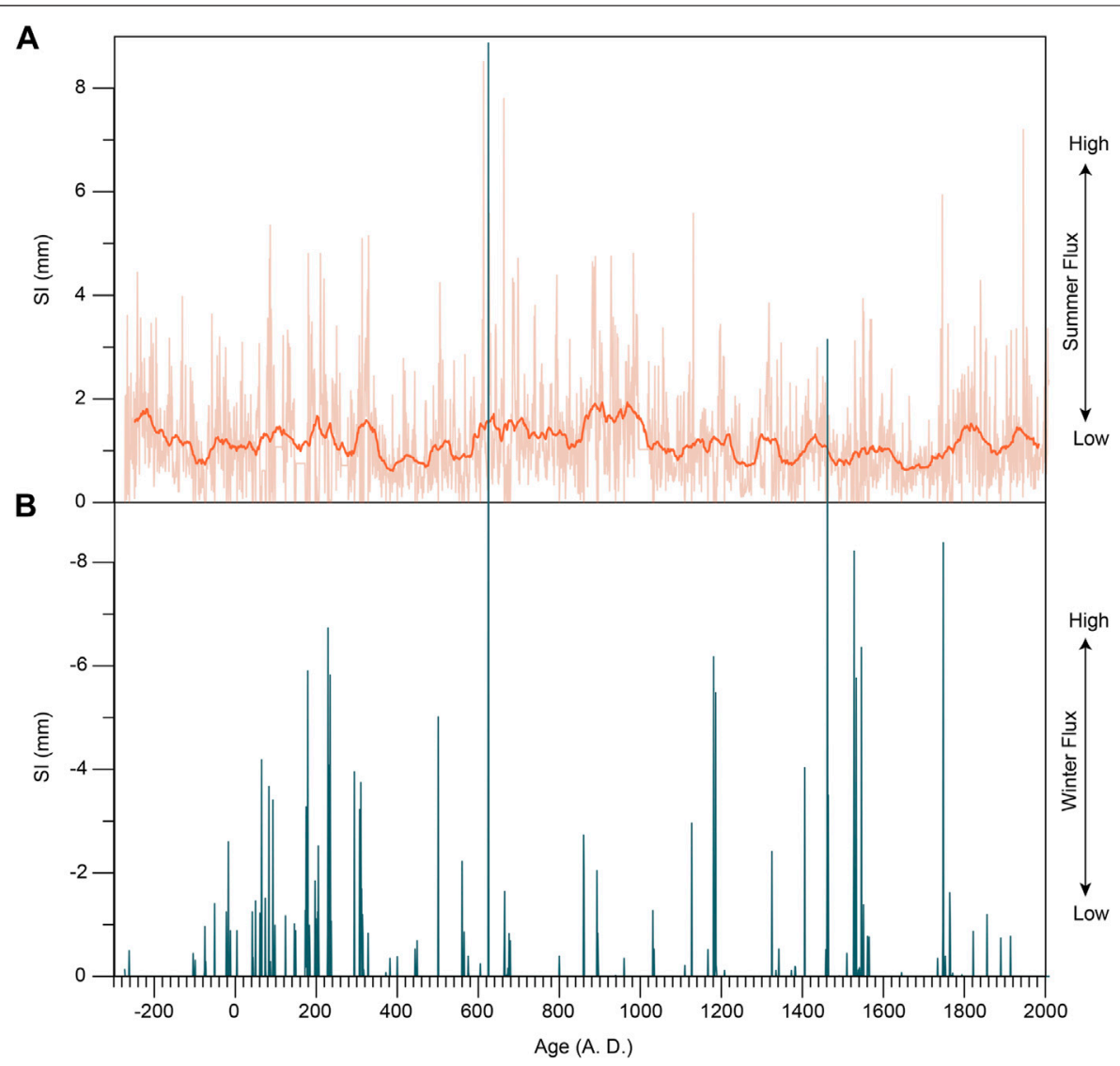

FIGURE 2 | Season Index (SI) of varved sediments in Kusai Lake during the last 2280 years. Positive SI represents more summer flux (A), and negative SI represents more winter flux (B). The red thick solid line is the 51-years moving average for the SI of summer flux.

at a water depth of $14.5 \mathrm{~m}$ in September 2010 and 2015 (Figure 1B), respectively. All sediment cores were stored in PVC tubes, transported to the laboratory, and then stored in a refrigerator at a constant temperature of $4^{\circ} \mathrm{C}$. The collected cores were split along the central axis with a core-cutting machine. The surface morphology of half of the core was described in detail and photographed. The other half of the core was divided and then vacuum freeze-dried, embedded in epoxy resin and cured into polished thin sections. Optical microscopic analyses were performed to study sedimentary microfacies, to count varves and to measure the varve thickness. The varve records were extended back to 2280 years from a composite core (KSS-1) (Zhang et al., 2021) obtained from KSS-2010 and KSS-2015 by matching visual stratigraphy and varve microfacies (Liu et al., 2014b; Chen, 2017). The chronology was discussed and established by Liu et al. (2014b) and Zhang et al. (2021). Previous studies have shown that varved Kusai Lake sediments are rhythmically laminated with the interaction of light and dark layers (Figure 1C) (Liu et al., 2014b; Chen Y. et al., 2016; Chen and Liu, 2016; Chen, 2017). The dark layers consisting of coarse sand and silt are deposited on lake ice by aeolian processes during winter when the temperature is low and the wind is strong, while the light layers containing thin materials, biological debris, and authigenic carbonate are deposited during summer. To determine whether there are more sediments deposited in winter or summer and to evaluate the influencing factors of seasonal flux to varved Kusai Lake sediments, we define a season index (SI) as $S I=L T-D T$. LT and DT are the thicknesses of the light and dark layer respectively. A positive SI represents more summer flux, and a negative SI indicates more winter flux.

The time series were analyzed to reveal periodic cycles in the SI of summer flux using the Fourier transform method with the spectral analysis program REDFIT 3.8 (Schulza and Mudelseeb, 2002). Significant peaks in the spectra were detected using confidence levels of 90, 95 and $99 \%$ relative to the estimated red-noise background. In addition, a MATLAB software package that produces a continuous wavelet (Torrence and Compo, 1998) was used to verify the periodicity of the spectral analysis. A cone of influence is included where edge effects cannot be ignored because the wavelet is not completely localized in time. The irregular black curves delineate a $95 \%$ confidence level against the red noise signal.

\section{RESULTS}

\section{Variations in Summer and Winter Flux for the Last 2280 years}

In general, the summer flux was higher than the winter flux, as SI values have been positive in most of the years for the last 

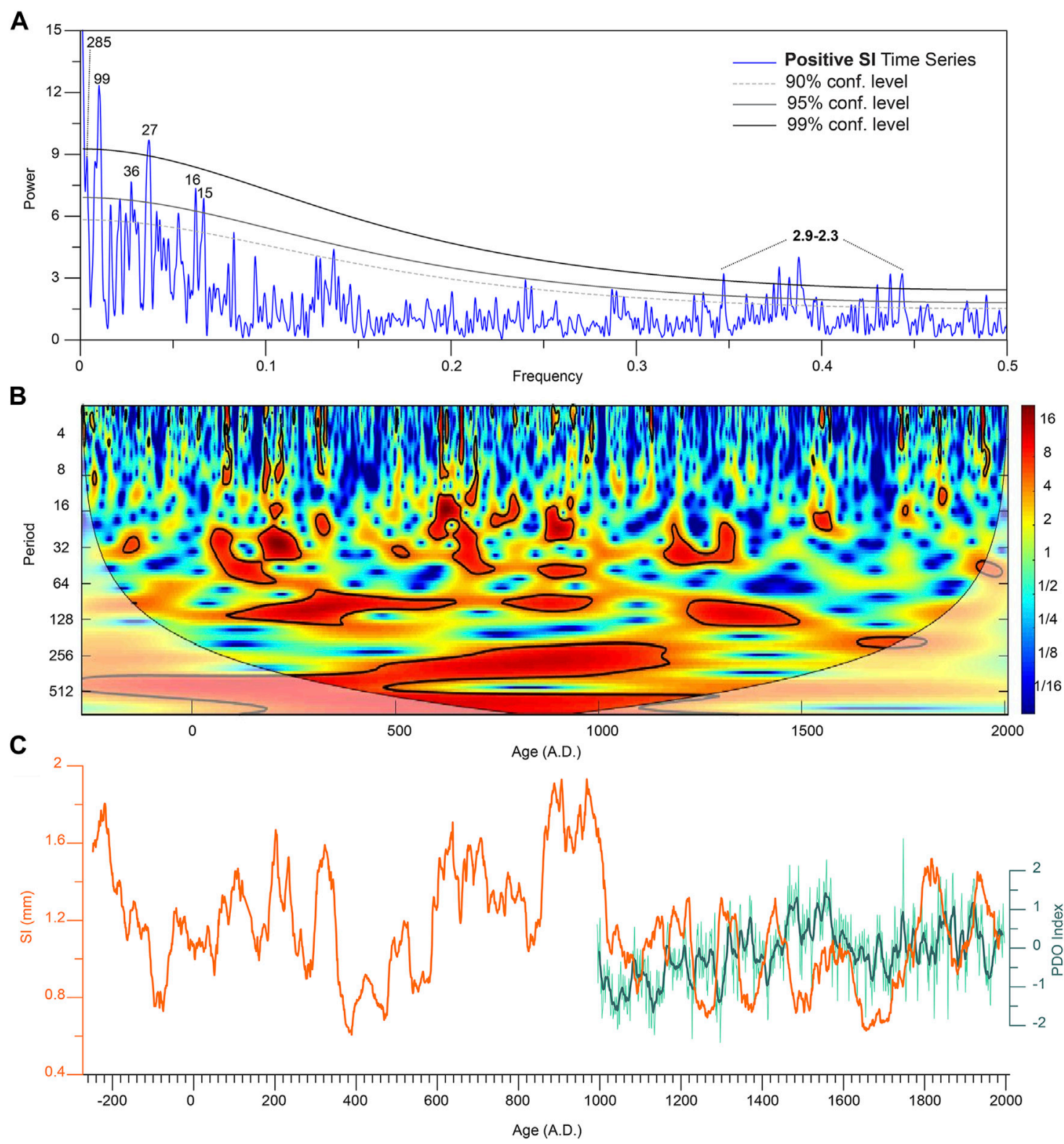

FIGURE 3 | Spectral (A) and wavelet (B) analyses of summer flux of the varved sediments of Kusai Lake during the last 2280 years. Morlet wavelet used with $\omega_{0}=6$. The black contour is the $95 \%$ significance level using a red noise background spectrum. The Cone of Influence (COI) is the area with lighter shading. The horizontal band corresponding to periodicity higher than 500 years is not meaningful (C) Comparison between the 51 -years moving average SI of the summer flux from Kusai Lake with the PDO reconstruction during the last 1000 years (MacDonald and Case, 2005).

2280 years (Figure 2), indicating that the varved sediments are mainly deposited in summer. Summer flux was relatively low in three periods from $270 \mathrm{BC}$ to $0 \mathrm{AD}$, from 350 to $600 \mathrm{AD}$, and from 1250 to $1800 \mathrm{AD}$ (Figure 2A). Three periods of high summer flux occurred from 0 to $350 \mathrm{AD}$, from 600 to 1250 $\mathrm{AD}$, and from $1800 \mathrm{AD}$ to present. The periods when the winter flux is higher than the summer flux are discontinuous (Figure 2B). However, noticeably increasing spikes in the winter flux can be observed from $100 \mathrm{BC}$ to $340 \mathrm{AD}$, at 229
$\mathrm{AD}, 625 \mathrm{AD}, 1180 \mathrm{AD}$, and $1462 \mathrm{AD}$, and at approximately 1530 $\mathrm{AD}$ and $1748 \mathrm{AD}$ (Figure 2B).

\section{Periodicity of Summer Flux in Varved Sediments of Kusai Lake}

Spectral analysis of the summer flux revealed several statistically significant power spectrum peaks. The outstanding peaks in the power spectrum occurred for approximately 2.3-2.9, 27, and 99 years 


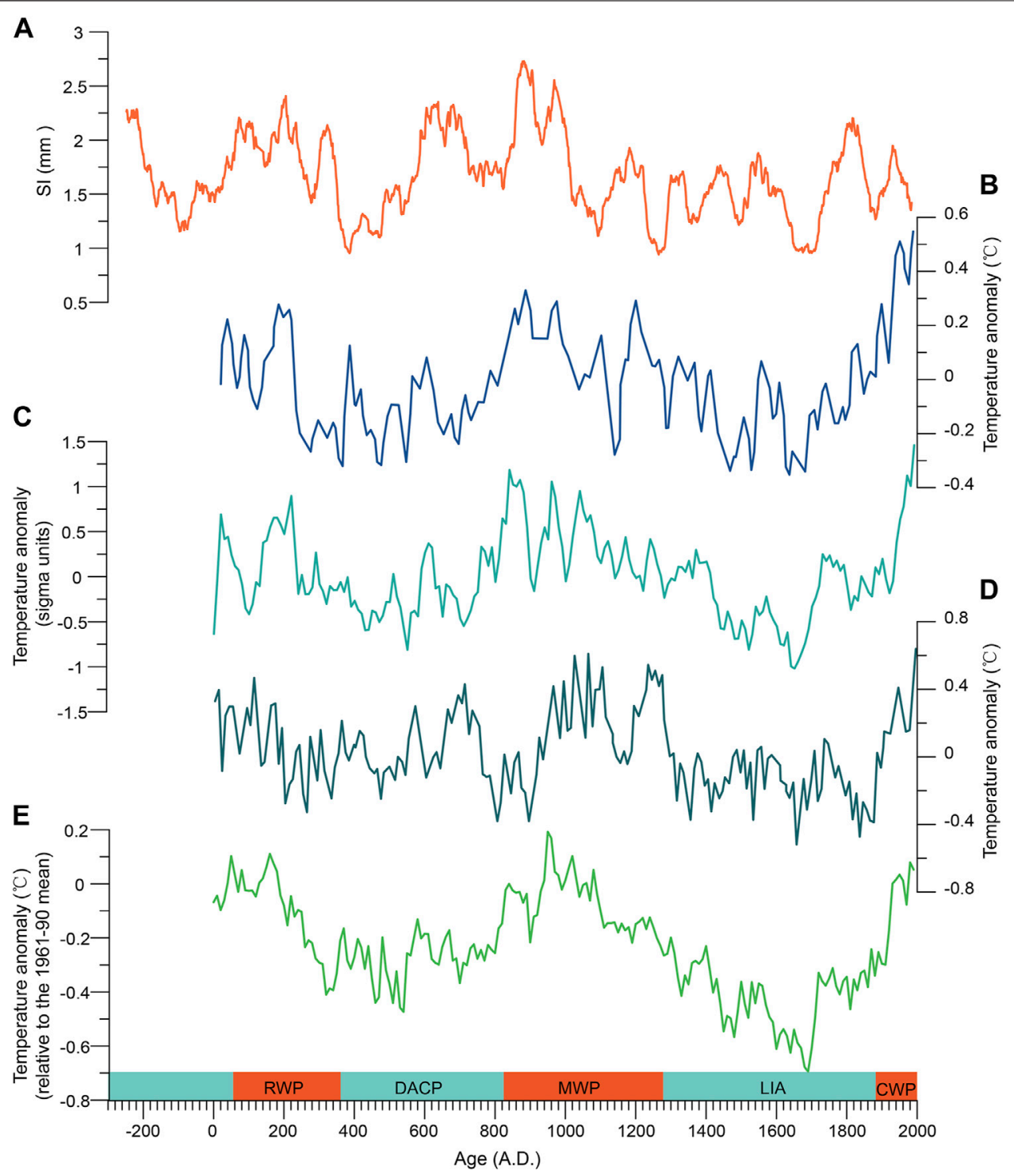

FIGURE 4 | 51 -years moving average SI of the summer flux from Kusai Lake (A) and its comparisons with integrated temperature series on the Tibetan Plateau (B) (Hou et al., 2012), temperature reconstructions for China (C) (Yang et al., 2002) and (D) (Ge et al., 2013), and the Northern Hemisphere (E) (Ljungqvist, 2010). RWP, DACP, MWP, LIA, and CWP refer to the Roman Warm Period, Dark Age Cold Period, Medieval Warm Period, Little Ice Age, and Current Warm Period, respectively.

at the $99 \%$ confidence level and approximately 15-16, 36, and 285 years at the 95\% confidence level (Figure 3A). These periodicities were also confirmed by wavelet results (Figure $\mathbf{3 B}$ ). The periodicity of 99 years was almost continuous during the last 2380 years, and the periodicity of 285 years was continuous from 280 $\mathrm{BC}$ to $1200 \mathrm{AD}$. In contrast, the periodicities of 2.3-2.9 years and 15-36 years were discontinuous. The more significant periodicity of 15-36 years corresponded well to a higher summer flux (Figures 3B,C).

\section{DISCUSSION}

\section{Influencing Factors of the Summer Flux}

Two periods with high summer flux from 0 to $350 \mathrm{AD}$, from 600 to $1250 \mathrm{AD}$ (Figure 4A) were well correlated with the Roman warm period, the Sui and Tang dynasty warm period in China and the Medieval Warm Period in Europe, respectively. It seems that summer flux is not very high during the Current Warm Period. Two periods with low summer flux from 350 to $600 \mathrm{AD}$ and from 1250 to $1800 \mathrm{AD}$ (Figure 4A) generally corresponded to the Dark Age Cold Period and the Little Ice Age respectively. Our reconstructed summer flux during the last 2280 years was generally in agreement with temperature variations from the TP (Figure 4B) (Hou et al., 2012), China (Figures 4C,D) (Yang et al., 2002; Ge et al., 2013), and the Northern Hemisphere (Figure 4E) (Ljungqvist, 2010), indicating that the summer flux of varved sediments from Kusai Lake is mainly related to temperature. Previous studies on varved sediments formed in glacial-fed lakes have demonstrated that varve thicknesses are physically linked to temperatures, as warm summers can often result in significant 

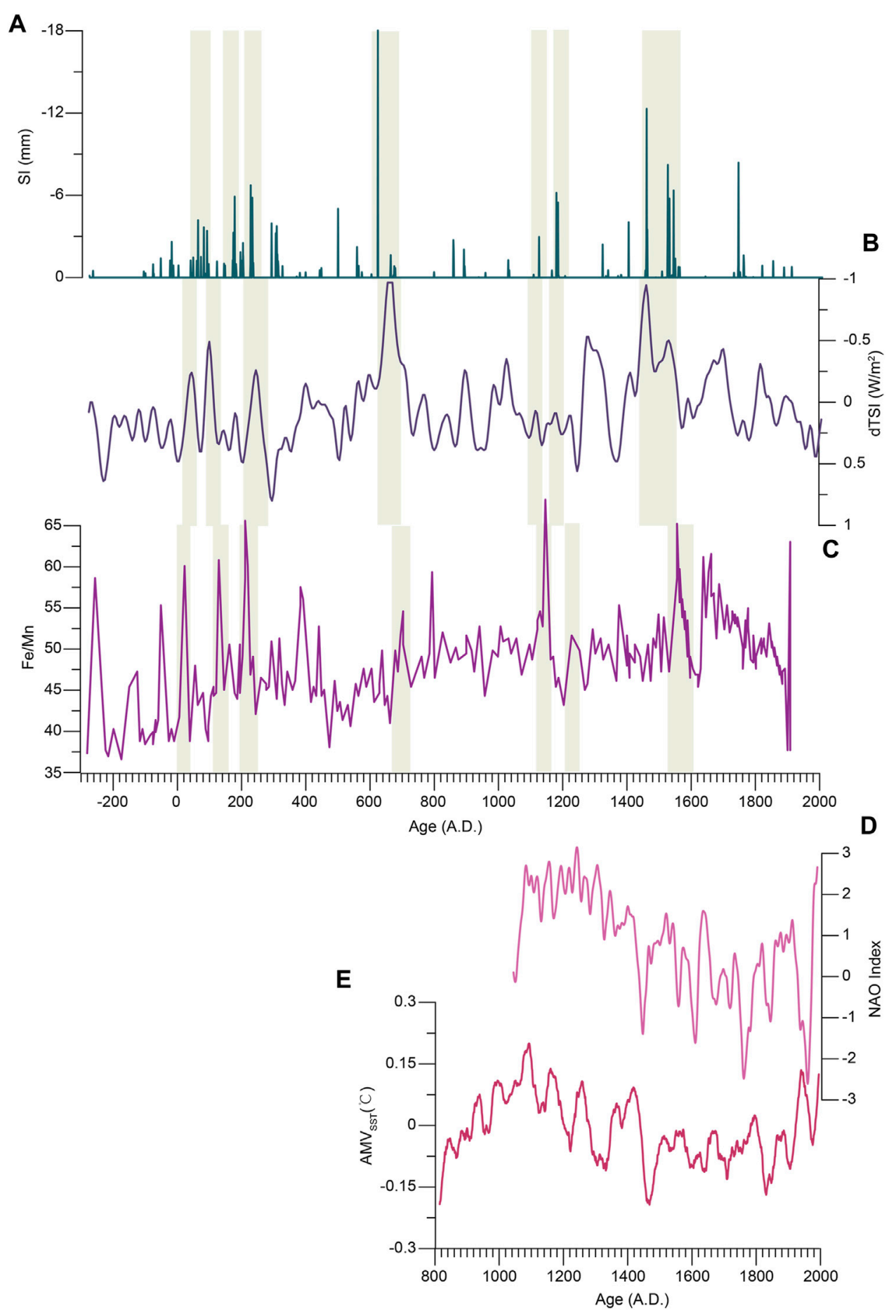

FIGURE 5 | SI of winter flux in Kusai Lake (A) and its comparisons with the dTSI record reconstructed from the cosmogenic radionuclide ${ }^{10}$ Be data (B) (Steinhilber et al., 2009), Fe/Mn ratio record from Lake Kalliojärvi as a proxy for SH (C) (Saarni et al., 2015), the winter NAO reconstructed by a speleothem-based precipitation proxy from Scotland and a tree-ring based drought proxy from Morocco (D) (Trouet et al., 2009), Multidecadal Variability of Atlantic sea surface temperature (AMV $\mathrm{SST}$, that is, the AMO) anomaly reconstructed based on a network of annual-resolution terrestrial proxy records from the circum-North Atlantic region (E) (Wang J. et al., 2017).

melting of glaciers and snowmelt and thus lead to high runoff and sediment flux to lakes (Moorel et al., 2001; Loso et al., 2006).

Summer flux has centennial-scale periodicities of 285 and 99 years (Figure 3A). The significant periodicities of 99 years strongly cohere with the classic Gleissberg cycle of solar activity (Gleissberg, 1958; Gleissberg, 1965; Ogurtsov et al., 2015). There is also a strong periodicity of approximately 285 years that corresponds to 350 unnamed cycle of the reconstructed solar activity time series 
(Steinhilber et al., 2012) and other records (Wang et al., 2005; Soon et al., 2014; Chang et al., 2017; Xie, 2020). The Gleissberg cycle of 99 years has also been observed in integrated temperature records from the TP during the last 2000 years (Hou et al., 2012) and in a 449years temperature reconstruction based on tree-ring from Bangda and Zuogong on the southeastern TP (Duan and Zhang, 2014). The $\mathrm{U}_{\mathrm{k}}{ }^{37}$ temperature records from Lake Sugan and Lake Gahai on the northern TP also show a possible link between solar irradiance and temperature variability during the last 2500 years (He et al., 2013a). Therefore, the summer flux of varved sediments from Kusai Lake is related to temperature influenced by solar activity at the centennial scale.

Most studies on tree rings (Shi et al., 2010; Wang et al., 2014), ice cores (Davis, 2005), and coral (Davis, 2005; Watanabe et al., 2014) have shown that the East Asian Summer Monsoon is intensified when the PDO is in its negative phase and vice versa. Our summer flux has a good negative relation with PDO reconstructed by MacDonald and Case (2005) during the last 1000 years at multidecadal scale (Figure 3C), especially from $1000 \mathrm{AD}$ to $1600 \mathrm{AD}$. Thus, the enhanced East Asian Summer Monsoon caused by negative $\mathrm{PDO}$ phase can bring more precipitation to the TP and result in more summer flux to Kusai Lake. At the decadal time scale, summer flux has periodicities of 15-16, 27 and 36 years that may be related to the Pacific Decadal Oscillation (PDO) (Cayan and Peterson, 1989; Ebbesmeyer et al., 1989; Mantua et al., 1997; Gershunov et al., 1999; Biondi et al., 2001). The periodicities of 15-36 years in summer flux are discontinuous but more significant in the period of higher summer flux corresponding well to a warmer period (Figures 3 and 4), indicating that PDO has more effect on summer flux to Kusai Lake in the warm period than in the cool period. The relationship between the winter PDO index and summer coral $\delta^{18} \mathrm{O}$ record from Shimo-Koshiki Island of Japan also suggested that recent and future global warming may lead to a more frequent and/or stronger teleconnection between the East Asian Summer Monsoon and PDO (Watanabe et al., 2014).

At the interannual scale, summer flux has periodicities of 2.3-2.9 years significant at the $99 \%$ confidence level. This may be caused by the Quasi-biennial Oscillation (QBO) (Reed et al., 1961; Gordon et al., 1982; Naujokat, 1986). The QBO was originally observed between westerly and easterly equatorial stratospheric winds by Reed et al. (1961). Previous studies have found the QBO period in the equatorial sea surface temperature record (Barnett, 1989; Chen et al., 1991b), and the interannual oscillation of SST has an obvious propagation phenomenon (Yasunari, 1985; Chen et al., 1989). Although the QBO was first noted as a tropical, lower stratospheric zonal wind variation, with a period of $\sim 26$ months, it has since been found to occur at high latitudes and in geophysical parameters other than winds aloft (Plumb, 1984). Studies on the correlation between the annual oscillation of the sea-air system and the annual oscillation of China's climate showed that there is a lag correlation between the SST QBO and China's air temperature QBO (Chen et al., 1990). The QBO can also be found in other regions of China (Huang and Tang, 1987; Chen et al., 1991a; Yang et al., 2019) Therefore, we consider that there is a possible link between the QBO and summer flux of varved sediments in Kusai Lake.

\section{Influencing Factors of Winter Flux}

Noticeable increasing spikes in the winter flux occurred from 100 $\mathrm{BC}$ to $340 \mathrm{AD}$, at $229 \mathrm{AD}, 625 \mathrm{AD}, 1180 \mathrm{AD}, 1462 \mathrm{AD}$, and approximately $1530 \mathrm{AD}$, corresponding to low values of total solar irradiance (TSI) and strong Siberian high pressure (SH) (Figure 5A-C). The winter surface air temperature over Asia and the surrounding oceans may be directly or indirectly related to solar activities due to the huge mass of the Eurasian continent (Miyazaki and Yasunari, 2008). A stronger SH system tends to be closely associated with lower solar activity (Figures 5B,C) and lower winter temperatures (Liang et al., 2014). The Siberian highpressure system significantly influences the near-surface wind strength in northeastern central Asia (Wang X. et al., 2017; Wang et al., 2018; Li Y. et al., 2019; Gao et al., 2020). Strong near-surface wind may bring dust from the surrounding arid Asian regions and partly from the plateau itself to Kusai Lake, resulting in a high winter flux (Figures 5A,C).

The periods of high winter flux occurred from $100 \mathrm{BC}$ to $340 \mathrm{AD}$, from $1400 \mathrm{AD}$ to $1600 \mathrm{AD}$, and approximately $1748 \mathrm{AD}$, generally corresponding to negative phases of the North Atlantic Oscillation (NAO) (Trouet et al., 2009) and Atlantic Multidecadal Oscillation (AMO) (Wang et al., 2014) (Figures 5A,D,E). Modern meteorological data and long-term simulations all indicated that the NAO may be related to dust emissions and the pattern and intensity of dust transport in many places around the world (Moulin et al., 1997; Ginoux et al., 2004). In China, there is an obvious inverse relationship between the winter NAO index and the frequency of strong dust storms in spring (Song et al., 2004). Based on the data for the period of 1958-1995, Gong and Wang (2003) found that there is a significant correlation $(\mathrm{r}=-0.51)$ between the NAO and SH. In a negative phase of the NAO (Figure 5D), the Artic circulation is weak, resulting in a high SH (Gong et al., 2001; Gong and Wang, 2003). With a high $\mathrm{SH}$, the intensity of dust transport increases in winter, leading to high winter flux to Kusai Lake and vice versa (Figures 5A,C,D). A negative phase of the AMO will result in a colder midupper tropospheric atmosphere over Eurasia, causing a strengthened land sea thermal contrast in winter and a strengthened East Asian winter monsoon (Li et al., 2009; Zhou et al., 2015) and thus high winter flux to Kusai Lake and vice versa. Therefore, the periods of high and low winter flux to Kusai Lake are generally related to the negative and positive phases of the NAO and AMO, respectively, during the last 1000 years.

\section{CONCLUSION}

In this study, we defined a season index to evaluate the factors influencing seasonal fluxes during the past 2280 years.

The positive SI represents more summer flux and shows good agreement with temperature variations during the last 2280 years. The spectral analysis results show that summer flux has periodicities of approximately 2.3-2.9, 27, and 99 years at the $99 \%$ confidence level and approximately 15-16, 36, and 285 years at the $95 \%$ confidence level. These significant periodicities indicate that summer flux is affected mainly by solar activity at centennial scales, by the PDO at decadal scales, and by the QBO at interannual scales. Winter flux has been discontinuous over the 
last 2280 years. Noticeable increasing spikes in winter flux, which occurred from $100 \mathrm{BC}$ to $340 \mathrm{AD}$, at $229 \mathrm{AD}, 625 \mathrm{AD}, 1180 \mathrm{AD}$, and $1462 \mathrm{AD}$, and approximately $1530 \mathrm{AD}$, correspond well to low TSI and strong SH. In addition, the periods of high winter flux from $1400 \mathrm{AD}$ to $1600 \mathrm{AD}$ and approximately $1748 \mathrm{AD}$ generally correspond to the negative phases of the NAO and AMO periods. We suggest that the winter flux of Kusai Lake is associated with solar activity, SH, NAO and AMO.

\section{DATA AVAILABILITY STATEMENT}

The raw data supporting the conclusions of this article will be made available by the authors, without undue reservation.

\section{REFERENCES}

Aichner, B., Feakins, S. J., Lee, J. E., Herzschuh, U., and Liu, X. (2015). Highresolution Leaf Wax Carbon and Hydrogen Isotopic Record of the Late Holocene Paleoclimate in Arid Central Asia. Clim. Past 11 (4), 619-633. doi:10.5194/cp-11-619-2015

An, Z., Colman, S. M., Zhou, W., Li, X., Brown, E. T., Jull, A. J. T., et al. (2012). Interplay between the Westerlies and Asian Monsoon Recorded in Lake Qinghai Sediments since 32 Ka. Sci. Rep. 2, 619. doi:10.1038/srep00619

Bao, Y. (2004). Evidence for a Late Holocene Warm and Humid Climate Period and Environmental Characteristics in the Arid Zones of Northwest China during $2.2 \sim 1.8$ Kyr B.P. J. Geophys. Res. 109 (D2). doi:10.1029/2003jd003787

Barnett, T. P. (1989). A Solar-Ocean Relation: Fact or Fiction? Geophys. Res. Lett. 16, 803-806. doi:10.1029/GL016i008p00803

Biondi, F., Gershunov, A., and Cayan, D. (2001). North Pacific Decadal Climate Variability since 1661. J. Clim. 14. doi:10.1175/1520-0442(2001)014<0005: npdcvs $>2.0 . c 0 ; 2$

Cayan, D. R., and Peterson, D. H. (1989). The Influence of North Pacific Atmospheric Circulation on Streamflow in the West, 55. Washington DC: American Geophysical Union Geophysical Monograph Series, 375-397. doi:10.1029/GM055p0375

Chang, J., Zhang, E., Liu, E., and Shulmeister, J. (2017). Summer Temperature Variability Inferred from Subfossil Chironomid Assemblages from the SouthEast Margin of the Qinghai-Tibetan Plateau for the Last 5000 Years. The Holocene 27 (12), 1876-1884. doi:10.1177/0959683617708456

Chen, D., Xu, B., Yao, T., Guo, Z., Cui, P., Chen, F., et al. (2015). Assessment of Past, Present and Future Environmental Changes on the Tibetan Plateau. Csb 12, 133. doi:10.1360/n972014-01370

Chen, F.-H., Chen, J.-H., Holmes, J., Boomer, I., Austin, P., Gates, J. B., et al. (2010). Moisture Changes over the Last Millennium in Arid central Asia: a Review, Synthesis and Comparison with Monsoon Region. Quat. Sci. Rev. 29 (7-8), 1055-1068. doi:10.1016/j.quascirev.2010.01.005

Chen, F., Yu, Z., Yang, M., Ito, E., Wang, S., Madsen, D. B., et al. (2008). Holocene Moisture Evolution in Arid central Asia and its Out-of-phase Relationship with Asian Monsoon History. Quat. Sci. Rev. 27, 351-364. doi:10.1016/ j.quascirev.2007.10.017

Chen, F., Zhang, Y., Shao, X., Li, M., and Yin, Z.-Y. (2016a). A 2000-year Temperature Reconstruction in the Animaqin Mountains of the Tibet Plateau, China. The Holocene 26 (12), 1904-1913. doi:10.1177/ 0959683616646187

Chen, L., Chen, D., Shen, R., and Zhang, Q. (1990). The International Oscillation of Rainfall Over China and its Relation to the Interannual Oscillation of the AirSea System. Acta Meteorol. Sin. 4, 598-612.

Chen, L., Shao, Y., and Zhang, Q. (1991a). Preliminary Analysis of Climate Change of China in Recent 40 Years. Q. J. Appl. Meteorology 2, 164-174

Chen, L., Yan, J., and Wang, G. (1989). Evolution Features of Interannual LowFrequency Oscillations and Their Relation to the Occurrence of El Nino. Acta Meteorologica Sinica 13, 352-365.

Chen, L., Zhu, Q., Luo, H., He, J., Dong, M., and Feng, Z. (1991b). East Asian Monsoon. Beijing: China meteorological press

\section{AUTHOR CONTRIBUTIONS}

QZ and XL designed this study; QZ and SF analyzed the data; QZ wrote the manuscript; QZ, XL and SF polished the paper. All authors approved the final version of the manuscript.

\section{FUNDING}

This study was supported by the Second Tibetan Plateau Scientific Expedition and Research Program (STEP), Grant No. 2019QZKK0202.

Chen, Y., Liu, X., He, L., Ye, L., Chen, H., and Li, K. (2016b). Micro Area Analysis and Mechanism of Varves from Lake Kusai in the Hoh Xil Area, Northern Tibetan Plateau. Acta Geologica Sinica 90 (5), 1006-1015. doi:10.3969/ j.issn.0001-5717.2016.05.013

Chen, Y. (2017). Reconfirmation and Formation Mechanism of Var Ved lake Sediments from Lake Kusai in the Hoh Xil Area, Northern Tibetan Plateau. Master, Capital Normal University

Chiang, J. C. H., Fung, I. Y., Wu, C.-H., Cai, Y., Edman, J. P., Liu, Y., et al. (2015). Role of Seasonal Transitions and westerly Jets in East Asian Paleoclimate. Quat. Sci. Rev. 108, 111-129. doi:10.1016/j.quascirev.2014.11.009

Chu, G., Sun, Q., Yang, K., Li, A., Yu, X., Xu, T., et al. (2011). Evidence for Decreasing South Asian Summer Monsoon in the Past 160 Years from Varved Sediment in Lake Xinluhai, Tibetan Plateau. J. Geophys. Res. 116 (D2). doi:10.1029/2010jd014454

Cui, A., Lu, H., Liu, X., Shen, C., Xu, D., Xu, B., et al. (2021). Tibetan Plateau Precipitation Modulated by the Periodically Coupled Westerlies and Asian Monsoon. Geophys. Res. Lett. 48 (7). doi:10.1029/2020gl091543

Davis, M. E. (2005). Forcing of the Asian Monsoon on the Tibetan Plateau: Evidence from High-Resolution Ice Core and Tropical Coral Records. J. Geophys. Res. 110 (D4). doi:10.1029/2004jd004933

Duan, J., and Zhang, Q.-B. (2014). A 449 Year Warm Season Temperature Reconstruction in the southeastern Tibetan Plateau and its Relation to Solar Activity. J. Geophys. Res. Atmos. 119 (20), 11. doi:10.1002/2014jd022422

Ebbesmeyer, C. C., Coomes, C. A., Cannon, G. A., and Bretschneider, D. E. (1989). Linkage of Ocean and Fjord Dynamics at Decadal Period, 55. Washington DC: American Geophysical Union Geophysical Monograph Series, 399-417. doi:10.1029/GM055p0399

Gao, F., Zheng, X., Jia, J., Li, K., Xia, D., Yang, J., et al. (2021). Evolution of NearSurface Wind Strength in Northeastern Arid Central Asia during the Holocene. Paleoceanogr Paleoclimatol 36. doi:10.1029/2020PA003970

Ge, Q., Hao, Z., Zheng, J., and Shao, X. (2013). Temperature Changes over the Past 2000 Yr in China and Comparison with the Northern Hemisphere. Clim. Past 9 (3), 1153-1160. doi:10.5194/cp-9-1153-2013

Gershunov, A., Barnett, T. P., and Cayan, D. R. (1999). North Pacific Interdecadal Oscillation Seen as Factor in ENSO-Related North American Climate Anomalies. Eos Trans. AGU 80, 25-30. doi:10.1029/99EO00019

Ginoux, P., Prospero, J., Torres, O., and Chin, M. (2004). Long-term Simulation of Global Dust Distribution with the GOCART Model: Correlation with North Atlantic Oscillation. Environ. Model. Softw. 19 (2), 113-128. doi:10.1016/s13648152(03)00114-2

Gleissberg, W. (1965). The Eighty-Year Solar Cycle in Auroral Frequency Numbers. J. Br. Astron. Assoc. 75, 227-231

Gleissberg, W. (1958). The Eighty-Year sunspot Cycle. J. Br. Astron. Assoc. 68, $148-152$

Gong, D.-Y., Wang, S.-W., and Zhu, J.-H. (2001). East Asian Winter Monsoon and Arctic Oscillation. Geophys. Res. Lett. 28 (10), 2073-2076. doi:10.1029/ $2000 \mathrm{gl} 012311$

Gong, D., and Wang, S. (2003). Influence of Arctic Oscillation on Winter Climate over China. Acta Geographica Sinica 58, 559-568. doi:10.11821/xb200304010

Gordon, A. H., Byron-Scott, R. A. D., and Bye, J. A. T. (1982). A Note on QBOSO Interaction, the Quasi-Triennial Oscillation and the Sunspot Cycle. 
J. Atmos. Sci. 39, 2083-2087. doi:10.1175/1520-0469(1982)039<2083: anoqsi $>2.0 . \mathrm{co} ; 2$

Guangliang, H., Chongyi, E, Xiangjun, L., and Fangming, Z. (2012). Reconstruction of Integrated Temperature Series of the Past 2,000 Years on the Tibetan Plateau with 10-year Intervals. Theor. Appl. Climatol 113 (1-2), 259-269. doi:10.1007/ s00704-012-0783-y

He, Y., Liu, W., Zhao, C., Wang, Z., Wang, H., Liu, Y., et al. (2013a). Solar Influenced Late Holocene Temperature Changes on the Northern Tibetan Plateau. Chin. Sci. Bull. 58 (9), 1053-1059. doi:10.1007/s11434-012-5619-8

He, Y., Zhao, C., Wang, Z., Wang, H., Song, M., Liu, W., et al. (2013b). Late Holocene Coupled Moisture and Temperature Changes on the Northern Tibetan Plateau. Quat. Sci. Rev. 80, 47-57. doi:10.1016/j.quascirev.2013.08.017

Hou, J., D'Andrea, W. J., Wang, M., He, Y., and Liang, J. (2017). Influence of the Indian Monsoon and the Subtropical Jet on Climate Change on the Tibetan Plateau since the Late Pleistocene. Quat. Sci. Rev. 163, 84-94. doi:10.1016/ j.quascirev.2017.03.013

Hou, J., Huang, Y., Zhao, J., Liu, Z., Colman, S., and An, Z. (2016). Large Holocene Summer Temperature Oscillations and Impact on the Peopling of the Northeastern Tibetan Plateau. Geophys. Res. Lett. 43 (3), 1323-1330. doi:10.1002/2015gl067317

Hu, D. (1994). Environmental Hydrochemistry of Lakes and Water System in Hoh Xil Area, Qinghai Province. Qinghai Environ. 4 (3), 136-142

Huang, S., and Tang, M. (1987). On the Structure of East Asian Summer Monsoon System. Meteorol. Sci. 7, 1-10

Ji, K., Zhu, E., Chu, G., Aquino-López, M. A., and Hou, J. (2021). A Record of Late Holocene Precipitation on the Central Tibetan Plateau Inferred from Varved lake Sediments. J. Paleolimnol 66, 439-452. doi:10.1007/s10933021-00215-8

Kang, X., Zhang, Q., Graumlich, L. J., and Sheppard, P. (2000). Reconstruction and Variation of Climate in Dulan Region, Qinghai during the Last 2000a. Adv. Earth Sci. 15, 215-221. doi:10.3321/j.issn:1001-8166.2000.02.015

Li, B., Gu, G., and Li, S. (1996). Physical Environment of Hoh Xil Region. Qinghai. Beijing: Science Press

Li, S., Wang, Y., and Gao, Y. (2009). A Review of Climate Influence on the Atlantic Multidecadal Oscillation (AMO). Trans. Atmos. Sci. 32, 458-465. doi:10.13878/ j.cnki.dqkxxb.2009.03.006

Li, X., Liang, J., Hou, J., and Zhang, W. (2015). Centennial-scale Climate Variability during the Past 2000 Years on the central Tibetan Plateau. The Holocene 25 (6), 892-899. doi:10.1177/0959683615572852

Li, X., Wang, M., and Hou, J. (2019a). Centennial-scale Climate Variability during the Past 2000 Years Derived from Lacustrine Sediment on the Western Tibetan Plateau. Quat. Int. 510, 65-75. doi:10.1016/j.quaint.2018.12.018

Li, X., Zhang, Y., Wang, M., Yan, J., Fan, B., Xing, W., et al. (2020). CentennialScale Temperature Change during the Common Era Revealed by Quantitative Temperature Reconstructions on the Tibetan Plateau. Front. Earth Sci. 8. doi:10.3389/feart.2020.00360

Li, Y., Song, Y., Qiang, M., Miao, Y., and Zeng, M. (2019b). Atmospheric Dust Variations in the Ili Basin, Northwest China, during the Last Glacial Period as Revealed by a High Mountain Loess-Paleosol Sequence. J. Geophys. Res. Atmos. 124 (15), 8449-8466. doi:10.1029/2019jd030470

Liang, S., Ding, Y., Zhao, N., and Sun, Y. (2014). Analysis of the Interdecadal Changes of the Wintertime Surface Air Temperature over mainland China and Regional Atmospheric Circulation Characteristics during 1960-2013. Chin. J. Atmos. Sci. 38, 974-992. doi:10.3878/j.issn.1006-9895.1401.13234

Liu, X., and Chen, B. (2000). Climatic Warming in the Tibetan Plateau during Recent Decades. Int. J. Climatol. 20, 1729-1742.

Liu, X., Herzschuh, U., Wang, Y., Kuhn, G., and Yu, Z. (2014a). Glacier Fluctuations of Muztagh Ata and Temperature Changes during the Late Holocene in Westernmost Tibetan Plateau, Based on Glaciolacustrine Sediment Records. Geophys. Res. Lett. 41 (17), 6265-6273. doi:10.1002/ $2014 \mathrm{gl} 1060444$

Liu, X., Yu, Z., Dong, H., and Chen, H.-F. (2014b). A Less or More Dusty Future in the Northern Qinghai-Tibetan Plateau? Sci. Rep. 4, 6672. doi:10.1038/ srep06672

Liu, Y., An, Z., Linderholm, H. W., Chen, D., Song, H., Cai, Q., et al. (2009). Annual Temperatures during the Last 2485 Years in the Mid-eastern Tibetan Plateau Inferred from Tree Rings. Sci. China Ser. D-earth Sci. 52 (3), 348-359. doi:10.1007/s11430-009-0025-z
Liu, Z., Henderson, A. C. G., and Huang, Y. (2006). Alkenone-based Reconstruction of Late-Holocene Surface Temperature and Salinity Changes in Lake Qinghai, China. Geophys. Res. Lett. 33 (9). doi:10.1029/2006gl026151

Ljungqvist, F. C. (2010). A New Reconstruction of Temperature Variability in the Extra-tropical Northern Hemisphere during the Last Two Millennia. Geografiska Annaler: Ser. A, Phys. Geogr. 92, 339-351. doi:10.1111/j.14680459.2010.00399.x

Loso, M., Anderson, R., Anderson, S., and Reimer, P. (2006). A 1500-year Record of Temperature and Glacial Response Inferred from Varved Iceberg Lake, Southcentral Alaska. Quat. Res. 66, 12-24. doi:10.1016/j.yqres.2005.11.007

MacDonald, G. M., and Case, R. A. (2005). Variations in the Pacific Decadal Oscillation over the Past Millennium. Geophys. Res. Lett. 32 (8). doi:10.1029/ 2005gl022478

Mantua, N. J., Hare, S. R., Zhang, Y., Wallace, J. M., and Francis, R. C. (1997). A Pacific Interdecadal Climate Oscillation with Impacts on Salmon Production. Bull. Amer. Meteorol. Soc. 78, 1069-1079. doi:10.1175/1520-0477(1997) 078<1069:apicow >2.0.co;2

Miyazaki, C., and Yasunari, T. (2008). Dominant Interannual and Decadal Variability of Winter Surface Air Temperature over Asia and the Surrounding Oceans. J. Clim. 21 (6), 1371-1386. doi:10.1175/2007jcli1845.1

Moorel, J. J., Hughen, K. A., Miller, G. H., and Overpeck, J. T. (2001). Little Ice Age Recorded in Summer Temperature Reconstruction from Varved. Sediments of Donard Lake, Baffin Island, Canada. J. Paleolimnol. 25, 503-517. doi:10.1023/A: 1011181301514

Moulin, C., Lambert, C. E., Dulac, F., and Dayan, U. (1997). Control of Atmospheric export of Dust from North Africa by the North Atlantic Oscillation. Nature 387, 691-694. doi:10.1038/42679

Naujokat, B. (1986). An Update of the Observed Quasi-Biennial Oscillation of the Stratospheric Winds over the Tropics. J. Atmos. Sci. 43, 1873-1877. doi:10.1175/1520-0469(1986)043<1873:auotoq >2.0.co;2

Ogurtsov, M., Lindholm, M., Jalkanen, R., and Veretenenko, S. (2015). Evidence for the Gleissberg Solar Cycle at the High-Latitudes of the Northern Hemisphere. Adv. Space Res. 55 (5), 1285-1290. doi:10.1016/j.asr.2014.11.031

Plumb, R. (1984). The Quasi-Biennial Oscillation. Dynamics of the Middle Atmosphere. Proc. US-Japan seminar, Honolulu 1982, 217. doi:10.1007/97894-009-6390-0_13

Reed, R. J., Campbell, W. J., Rasmussen, L. A., and Rogers, D. G. (1961). Evidence of a Downward-Propagating, Annual Wind Reversal in the Equatorial Stratosphere. J. Geophys. Res. 66, 813-818. doi:10.1029/JZ066i003p00813

Saarni, S., Saarinen, T., and Dulski, P. (2015). Between the North Atlantic Oscillation and the Siberian High: A 4000-year Snow Accumulation History Inferred from Varved lake Sediments in Finland. The Holocene 26 (3), 423-431. doi:10.1177/0959683615609747

Schulz, M., and Mudelsee, M. (2002). REDFIT: Estimating Red-Noise Spectra Directly from Unevenly Spaced Paleoclimatic Time Series. Comput. Geosciences 28, 421-426. doi:10.1016/S0098-3004(01)00044-9

Shi, C., Masson-Delmotte, V., Daux, V., li, Z., and Zhang, Z. (2010). An Unstable Tree-Growth Response to Climate in Two 500 Year Chronologies, North Eastern Qinghai-Tibetan Plateau. Dendrochronologia 28, 225-237. doi:10.1016/j.dendro.2009.12.002

Song, L., Yu, Y., Sun, X., and Sun, G. (2004). Relationship between Arctic Oscillation and Spring Severe Sandstorm in North China. Plateau Meteorology 23, 835-839. doi:10.3321/j.issn:1000-0534.2004.06.015

Soon, W., Velasco Herrera, V. M., Selvaraj, K., Traversi, R., Usoskin, I., Chen, C.-T. A., et al. (2014). A Review of Holocene Solar-Linked Climatic Variation on Centennial to Millennial Timescales: Physical Processes, Interpretative Frameworks and a New Multiple Cross-Wavelet Transform Algorithm. Earth-Science Rev. 134, 1-15. doi:10.1016/j.earscirev.2014.03.003

Steinhilber, F., Abreu, J. A., Beer, J., Brunner, I., Christl, M., Fischer, H., et al. (2012). 9,400 Years of Cosmic Radiation and Solar Activity from Ice Cores and Tree Rings. Proc. Natl. Acad. Sci. 109 (16), 5967-5971. doi:10.1073/ pnas. 1118965109

Steinhilber, F., Beer, J., and Fröhlich, C. (2009). Total Solar Irradiance during the Holocene. Geophys. Res. Lett. 36. doi:10.1029/2009GL040142

Thompson, L. G., Mosley-Thompson, E., Davis, M. E., Lin, P.-N., Henderson, K., and Mashiotta, T. A. (2003). Tropical Glacier and Ice Core Evidence of Climate Change on Annual to Millennial Time Scales. Climatic Change 59, 137-155. doi:10.1007/978-94-015-1252-7_8 
Thompson, L. G., Tandong, Y., Davis, M. E., Mosley-Thompson, E., Mashiotta, T. A., Lin, P.-N., et al. (2006). Holocene Climate Variability Archived in the Puruogangri Ice Cap on the central Tibetan Plateau. Ann. Glaciol. 43, 61-69. doi:10.3189/172756406781812357

Thompson, L. G., Yao, T., Davis, M. E., Henderson, K. A., Mosley-Thompson, E., Lin, P.-N., et al. (1997). Tropical Climate Instability: The Last Glacial Cycle from a Qinghai-Tibetan Ice Core. Science 276, 1821-1825. doi:10.1126/ science.276.5320.1821

Torrence, C., and Compo, G. P. (1998). A Practical Guide to Wavelet Analysis. Bull. Amer. Meteorol. Soc. 79, 61-78

Trouet, V., Esper, J., Graham, N. E., Baker, A., Scourse, J. D., and Frank, D. C. (2009). Persistent Positive North Atlantic Oscillation Mode Dominated the Medieval Climate Anomaly. Science 324, 78-80. doi:10.1126/science.1166349

Wang, F., Li, Z., Wang, X., Li, B., and Chen, F. (2018). Variation and Interplay of the Siberian High and Westerlies in central-east Asia during the Past $1200 \mathrm{Kyr}$. Aeolian Res. 33, 62-81. doi:10.1016/j.aeolia.2018.05.003

Wang, J., Yang, B., Ljungqvist, F. C., Luterbacher, J., Osborn, T. J., Briffa, K. R., et al. (2017a). Internal and External Forcing of Multidecadal Atlantic Climate Variability over the Past 1200 Years. Nat. Geosci 10, 512-517. doi:10.1038/ ngeo2962

Wang, J., Yang, B., Qin, C., and Kang, S. (2014). Spatial Patterns of Moisture Variations across the Tibetan Plateau during the Past 700 Years and Their Relationship with Atmospheric Oscillation Modes. Int. J. Climatol. 34 (3), 728-741. doi:10.1002/joc.3715

Wang, S., and Dou, H. (1998). Records of Chinese Lakes. Beijing: Science Press

Wang, X., Lang, L., Hua, T., Zhang, C., and Li, H. (2017b). The Effects of Sorting by Aeolian Processes on the Geochemical Characteristics of Surface Materials: a Wind Tunnel experiment. Front. Earth Sci. 12 (1), 86-94. doi:10.1007/s11707-017-0619-2

Wang, Y., Cheng, H., Edwards, R. L., He, Y., Kong, X., An, Z., et al. (2005). The Holocene Asian Monsoon: Links to Solar Changes and North Atlantic Climate. Science 308, 854-857. doi:10.1126/science.1106296

Wang, Y., Liu, X., Herzschuh, U., Yang, X., Birks, H. J. B., Zhang, E., et al. (2012). Temporally Changing Drivers for Late-Holocene Vegetation Changes on the Northern Tibetan Plateau. Palaeogeogr. Palaeoclimatol. Palaeoecol. 353-355, 10-20. doi:10.1016/j.palaeo.2012.06.022

Watanabe, T., Kawamura, T., Yamazaki, A., Murayama, M., and Yamano, H. (2014). A 106 Year Monthly Coral Record Reveals that the East Asian Summer Monsoon Modulates winter PDO Variability. Geophys. Res. Lett. 41 (10), 3609-3614. doi:10.1002/2014gl060037

Wu, X., Liu, X., Wang, J., and Yamamoto, M. (2018). Climatic and Ecological Changes of the Past 1900 Years Inferred from Long-Chain Alkenones in Kusai Lake, Northern Qinghai-Tibetan Plateau. Quat. Int. 487, 33-42. doi:10.1016/ j.quaint.2018.02.007

Xie, C. (2020). Century Temperature Reconstruction and Holocene Climatechange Cycle Analysis in Lugu Lake Area Master Degree. Chengdu University of Technology

Yang, B., Braeuning, A., Johnson, K. R., and Yafeng, S. (2002). General Characteristics of Temperature Variation in China during the Last Two Millennia. Geophys. Res. Lett. 29 (9), 38. doi:10.1029/2001gl014485

Yang, B., Chen, X., He, Y., Wang, J., and Lai, C. (2019). Reconstruction of Annual Runoff since CE 1557 Using Tree-Ring Chronologies in the Upper LancangMekong River basin. J. Hydrol. 569, 771-781. doi:10.1016/j.jhydrol.2018.12.034

Yao, T. D., Thompson, L. G., Qin, D. H., Tian, L. D., Jiao, K. Q., Yang, Z. H., et al. (1996). Variations in Temperature and Precipitation in the Past 2000a on the Xizang (Tibet) Plateau - Guliya Ice Core Record. Sci. China Ser. D-Earth Sci. 39 (4), 425-433
Yao, T., Masson-Delmotte, V., Gao, J., Yu, W., Yang, X., Risi, C., et al. (2013). A Review of Climatic Controls on $\delta 18 \mathrm{O}$ in Precipitation over the Tibetan Plateau: Observations and Simulations. Rev. Geophys. 51 (4), 525-548. doi:10.1002/ $\operatorname{rog} .20023$

Yao, T., Thompson, L. G., Mosbrugger, V., Zhang, F., Ma, Y., Luo, T., et al. (2012). Third Pole Environment (TPE). Environ. Dev. 3, 52-64. doi:10.1016/ j.envdev.2012.04.002

Yao, T., Wu, F., Ding, L., Sun, J., Zhu, L., Piao, S., et al. (2015). Multispherical Interactions and Their Effects on the Tibetan Plateau's Earth System: a Review of the Recent Researches. Natl. Sci. Rev. 2 (4), 468-488. doi:10.1093/nsr/nwv070

Yao, T., Wu, G., Xu, B., Wang, W., Gao, J., and An, B. (2019). Asian Water Tower Change and its Impacts. Chin. Sci. Bull. 34, 1203-1209. doi:10.16418/ j.issn.1000-3045.2019.11.003

Yasunari, T. (1985). Zonally Propagating Modes of the Global East-West Circulation Associated with the Southern Oscillation. J. Meteorol. Soc. Jpn. 63, 1013-1029. doi:10.2151/jmsj1965.63.6_1013

Yu, C., Liu, X., and Xingqi, L. (2016). Surface Textural Analysis of Quartz Grains from Varved Sediments of Lake Kusai in the Hoh Xil Area, Tibetan Plateau. J. Lake Sci. 28 (5), 1123-1133. doi:10.18307/2016.0523

Zhang, Q., Liu, X., and Li, H. (2021). Impact of Hydrological Conditions on the Radiocarbon Reservoir Effect in lake Sediment 14C Dating: the Case of Kusai Lake on the Northern Qinghai-Tibet Plateau. Quat. Geochronol. 62, 101149. doi:10.1016/j.quageo.2020.101149

Zhang, Y., Shao, X., Yin, Z.-Y., and Wang, Y. (2014). Millennial Minimum Temperature Variations in the Qilian Mountains, China: Evidence from Tree Rings. Clim. Past Discuss. 10, 314-380. doi:10.5194/cpd-10-341-2014

Zhao, Q., and Zhou, Y. (2002). Distribution Characteristics of Sandstorm and its Relationship with Gale Weather in Qinghai Province. Qinghai Meteorol. 3, $12-16$

Zhou, X., Li, S., Luo, F., Gao, Y., and Furevik, T. (2015). Air-sea Coupling Enhances the East Asian winter Climate Response to the Atlantic Multidecadal Oscillation. Adv. Atmos. Sci. 32 (12), 1647-1659. doi:10.1007/s00376-0155030-x

Zhu, L., Lü, X., Wang, J., Peng, P., Kasper, T., Daut, G., et al. (2015). Climate Change on the Tibetan Plateau in Response to Shifting Atmospheric Circulation since the LGM. Sci. Rep. 5, 13318. doi:10.1038/srep13318

Conflict of Interest: The reviewer XC declared a past co-authorship with one of the authors XL to the handling Editor.

The authors declare that the research was conducted in the absence of any commercial or financial relationships that could be construed as a potential conflict of interest.

Publisher's Note: All claims expressed in this article are solely those of the authors and do not necessarily represent those of their affiliated organizations, or those of the publisher, the editors and the reviewers. Any product that may be evaluated in this article, or claim that may be made by its manufacturer, is not guaranteed or endorsed by the publisher.

Copyright (๑) 2022 Zhang, Liu and Feng. This is an open-access article distributed under the terms of the Creative Commons Attribution License (CC BY). The use, distribution or reproduction in other forums is permitted, provided the original author $(s)$ and the copyright owner(s) are credited and that the original publication in this journal is cited, in accordance with accepted academic practice. No use, distribution or reproduction is permitted which does not comply with these terms. 